\title{
DUE PROCESS IN CRIMINAL COURTS MARTIAL
}

Logically it would seem that the protection of the Bill of Rights would extend as well to the members of the armed forces as to their civilian compatriots. Although the court martial system is set up under Article I, Section 8 of the United States Constitution ${ }^{1}$ while the federal court system is set up under Article III, ${ }^{2}$ this in no way implies that while the latter is subject to such limitations as the Fourth through Eighth Amendments the former is unaffected by any portion of the Constitution. On the contrary, while the Constitution does not authorize direct review in the federal courts of court martial convictions, it does make such convictions subject to attack by habeas corpus under Article I, Section 9. ${ }^{3}$ Further indication of the limitations imposed upon the court martial system by the Constitution is shown in the Fifth Amendment, where it was thought necessary to state explicitly that the requirement of grand jury indictment did not apply to the armed forces. The implication of this one exception is that the unexcepted portions of the Amendment do apply. ${ }^{4}$ Since the power of courts martial is admittedly limited by the availability of habeas corpus to upset their convictions, how can it be said they are immune from due process?

The United States Supreme Court has said just this by way of dictum, however: "American citizens conscripted into the military service are thereby stripped of their Fifth Amendment rights." In cases concerning court martial convictions of United States citizen members of our armed forces, some federal courts have acted as if this statement were a valid expression of the law concerning all court martial decisions. ${ }^{6}$ Since courts martial are tribunals of limited jurisdiction whose judgment carries no presumption of validity, ${ }^{7}$ collateral attack on their judgments has allowed the civil courts at least to question their jurisdiction. ${ }^{8}$ The cases denying to servicemen the constitutional rights enjoyed by all other citizens are based on a narrow concept of "jurisdiction," under which the only facets of the court martial into which the civil courts may inquire are whether the defendant was subject to military law, ${ }^{9}$ whether the of-

${ }^{1}$ In Clause 14, Congress is authorized "To make rules for the government and regulation of the land and naval forces."

${ }^{2}$ See Winthrop, Military Law and Precedents 53 (2d ed., 1896).

${ }^{3}$ Clause 2. See, e.g., Ex parte Milligan, 4 Wall. (U.S.) 2 (1866).

${ }^{4}$ See Sanford v. Robbins, 115 F. 2d 435, 438 (C.A. 5th, 1940).

5 Johnson v. Eisentrager, 339 U.S. 763, 783 (1950) (trial by military tribunal of enemy alien war criminals).

- The most extreme statement of this position was made by the Court of Military Appeals, speaking of due process. "[W]e do not bottom those rights and privileges on the Constitution. We base them on the laws as enacted by Congress," and "we need not concern ourselves with the constitutional concepts." United States v. Clay (No. 49), 1 C.M.R. 74, 77, 79 (C.M.A., 1951).

7 Runkle v. United States, 122 U.S. 543, 555-56 (1887).

8 McClaughry v. Deming, 186 U.S. 49 (1902).

' In re Grimley, 137 U.S. 147 (1890). 
fense was cognizable by court martial, ${ }^{10}$ whether the tribunal was properly convened, ${ }^{11}$ and whether the sentence was within its authority to impose. ${ }^{12}$ These cases conflict with the basic notion that "due process," in criminal cases at least, is the right of all Americans.

As a result of this conflict, confusion exists regarding the permissible scope of habeas corpus attack upon court martial convictions. The best exposition of this confusion comes in the connected cases of Anthony v. Hunter ${ }^{13}$ and Arnold v. Cozart. ${ }^{14}$ Petitioners, codefendants in the same court martial, had been sentenced to serve in different penitentiaries and had therefore petitioned different district courts on habeas corpus. Anthony was released on the ground that improprieties in his pretrial investigation ${ }^{15}$ had constituted a denial of due process; it was taken for granted that habeas corpus could free one thus unconstitutionally convicted. Arnold, on the other hand, was curtly remanded to custody on the theory that such improprieties did not deprive the court martial of jurisdiction. Although the conflict in these cases most directly concerned the importance of the pretrial investigation, ${ }^{16}$ it was also involved with the larger question of due process as a whole.

More widespread evidence of the conflict between due process and the sanctity of court martial decisions appears in other current cases. A selective reading of these cases might lead to the conclusion that lack of due process in a court martial would clearly be grounds for the voiding of its judgment by a civil court on habeas corpus. The leadership along this road has been taken by the lower federal courts. Shapiro v. United States ${ }^{17}$ held that a court martial decision would not be respected where defendant was notified of the charges only eighty minutes before trial and was convicted less than five hours later. Beets v. Hunter ${ }^{18}$ freed petitioner because he had been defended at the court martial by incompetent and unwilling counsel. In Hicks v. Hiatt, ${ }^{19}$ had the case not been mooted by the army's returning defendant to duty, habeas corpus would have voided a highly irregular court martial. Even when the facts of the case have not been

${ }^{20}$ Collins v. McDonald, 258 U.S. 416 (1922).

${ }^{11}$ United States v. Brown, 206 U.S. 240 (1907).

${ }^{12}$ Carter v. McClaughry, 183 U.S. 365 (1902).

1371 F. Supp. 823 (D. Kan., 1947).

1475 F. Supp. 47 (N.D. Tex., 1948).

${ }^{15}$ Under Article of War 70, 41 Stat. 802 (1920), a pretrial investigation was required for general courts martial.

${ }^{16}$ It has now been held not jurisdictional in Humphrey v. Smith, 336 U.S. 695 (1949).

${ }^{17} 69$ F. Supp. 205 (Ct. Cl., 1947).

1875 F. Supp. 825 (D. Kan., 1948). The case was reversed without prejudice on failure to exhaust administrative remedies. Hunter v. Beets, 180 F. 2d 101 (C.A. 10th, 1950), cert. denied, 339 U.S. 963 (1950). On review under Article of War 53, 62 Stat. 604 (1948), the military review board held petitioner's allegations unfounded and opined that the district court had not been presented with all the facts by respondent warden. In re Beets, JAGY CM 296265, [1949-50] Memo. Ops. JAG Army 392.

${ }^{19} 64$ F. Supp. 238 (M.D. Pa., 1946). 
such as to warrant release, the courts have asserted their right to grant relief in appropriate cases. ${ }^{20}$

The Supreme Court also has spoken as if accepting in principle the idea that habeas corpus lies to free the victim of an unconstitutionally unfair court martial. It has strongly implied that denial of an opportunity to plead insanity in a court martial would be such an unconstitutional deprivation of the defendant's rights that it would void the court martial of "jurisdiction." "21 Similarly, it has held applicable the same general rule of law as is used in the civil courts for cases concerning necessary discontinuation of trials. ${ }^{22}$

Unfortunately, however, even though the Supreme Court has given verbal approval to the principle of broad use of habeas corpus, it has not been willing to put this principle into practice. In Hiatt v. Brown, ${ }^{23}$ the Court found no lack of due process in a court martial including the following errors: (1) the defendant was convicted of murder on the theory that even though he was a sentry on post, he was under an obligation to retreat; (2) no malice or premeditation was shown; (3) defense counsel was incompetent, gave no preparation to the case, and submitted only a token defense. The Court appeared to ignore the facts that had the sentry left his post he could have been court martialed under Article of War 86; that homicide without malice or premeditation is not murder ${ }^{24}$ save in felony-murder cases; and that denial of effective counsel is as bad as denial of all counsel. ${ }^{25}$ In dismissing petitioner's plea, the Court appeared to accept a narrow concept of jurisdiction. "In this case the court martial had jurisdiction of the person accused and the offense charged, and acted within its lawful powers. The correction of any errors it may have committed is for the military authorities. ${ }^{26}$ If the court martial errors found in this case are to be ignored on petition for habeas corpus, it is hard to imagine any that would be considered.

Although attempts have been made to explain away Hiatt v. Brown, ${ }^{27}$ its sig-

${ }^{20}$ Schita v. King, 133 F. 2d 283 (C.A. 8th, 1943) (incompetent defense counsel and improper admission of evidence would void conviction); Boone v. Nelson, 72 F. Supp. 807 (D. Me., 1947), Hayes v. Hunter, 83 F. Supp. 940 (D. Kan., 1948) (absolute failure of evidence would deprive court martial of jurisdiction); Powers v. Hunter, 178 F. 2d 141 (C.A. 10th, 1949), Benjamin v. Hunter, 169 F. 2 d 512 (C.A. 10th, 1948) (sentence so long as to violate constitutional prohibition of cruel and unusual punishment would be void even if within power of court martial). Of course there are many cases where relief would most clearly be inappropriate, e.g., Romero v. Squier, 133 F. 2d 528 (C.A. 9th, 1943) (civilian counsel refused access to secret military maps).

${ }^{21}$ Whelchel v. MCDonald, 340 U.S. 122 (1950) (but court martial upheld on facts).

${ }^{22}$ Wade v. Hunter, 336 U.S. 684, 690 (1949) (court martial upheld on facts). "We see no reason' why the same broad test should not be applied in deciding whether Court-Martial action runs counter to the Fifth Amendment's provision against double jeopardy. Measured by the Perez rule to which we adhere, petitioner's second Court-Martial trial was not the kind of double jeopardy within the intent of the Fifth Amendment."

23339 U.S. 103 (1950). 24 4 Bl. Comm. 198.

${ }^{25}$ von Moltke v. Gilles, 332 U.S. 708 (1948).

${ }^{26}$ Hiatt v. Brown, 339 U.S. 103, 111 (1950).

${ }^{27}$ Cf. Burns v. Lovett, 202 F. 2d 335 (App. D.C., 1952). 
nificance quite clearly seems to be that lip service only will be paid to the ideal of correcting unconstitutional court martial trials by habeas corpus. Support for this view is contained in Burns v. Lovett, ${ }^{28}$ where the allegations of unconstitutionality were at least such as to require a hearing on their veracity. Even before Hiatt v. Brown, some of the lower courts refused to follow the path of liberalism set out by their brethren, and took in both theory and practice the stand that courts martial are above the guarantees of the Bill of Rights. Even the Court of Appeals for the Second Circuit has said, "The Fifth and Sixth Amendments are, of course, inapplicable to a court martial." ${ }^{29}$ Similar ideas have been expressed in the District Courts. ${ }^{30}$ Once the effects of Hiall v. Brown are felt in the lower courts, there may well be a further retrogression from the broad use of habeas corpus. ${ }^{31}$

Since the law is made up of precedent as well as logic, the solution to any legal conflict should be in line with both. The solution in this case certainly should not allow the civil courts to "virtually administer the Rules and Articles of War, irrespective of those to whom that duty and obligation has been confided" ${ }^{22}$ by the Constitution and pertinent statutes. ${ }^{33}$ But neither does it mean that the Bill of Rights may be ignored. Fortunately, however, an examination of the statutory and common-law material dealing with the court martial system shows that the conflict, although serious, is unnecessary.

The background and composition of our system of military justice reveals that two distinct categories of offense render the soldier who commits them liable to trial. One category, the "disciplinary," encompasses offenses relating to the functioning of the army as an efficient and unified organization: offenses whose gravamen lies in their effect upon the service as a whole rather than upon those directly concerned. ${ }^{34}$ Such cases, therefore, are put solely and fully under the court martial jurisdiction of those directly responsible for the successful

28202 F. 2d 335 (App. D.C., 1952), cert. granted 73 S. Ct. 284 (1952), argued Feb. 5, 1953; (allegations of coerced confessions, suppression of evidence, unlawful detention, interference with counsel, and attempts to suborn perjury and intimidate witnesses held insufficient to warrant a hearing).

${ }_{29}$ United States ex rel. Innes v. Crystal, 131 F. 2d 576 (C.A. 2d, 1943), citing Ex parte Quirin, 317 U.S. 1, 43-44 (1942).

${ }^{30}$ E.g., Ex parte Benton, 63 F. Supp. 808 (N.D. Cal., 1945); United States ex rel. Marino v. Hildreth, 61 F. Supp. 667 (E.D. N.Y., 1945); In re Wrublewski, 71 F. Supp. 143 (S.D. Cal., 1947).

${ }^{31}$ See, e.g., Barrett v. Steele, 181 F. 2d 500 (C.A. 8th, 1950) (allegation of complete failure of evidence disregarded as not jurisdictional). Cf. Wiener, The Uniform Code of Military Justice 186 (1950).

32 Dynes v. Hoover, 20 How. (U.S.) 65, 82 (1858).

${ }^{33}$ The statute now in force is the Uniform Code of Military Justice (hereinafter cited as UCMJ), 64 Stat. 108 (1950), 50 U.S.C.A. $\$ 551$ et seq. (1951).

${ }^{34}$ Such offenses as insubordination, desertion, and dereliction of duty obviously strike at the root of the organization and discipline so essential to the survival of an army. 
operation of the service. ${ }^{35}$ In these "disciplinary" cases it is quite legitimate to say: "To those in the military or naval service of the United States the military law is due process." 36 In such a tightly knit and cohesive organization as the army, effective operation must of necessity depend on factors often considered unimportant in civilian life. Since the sole object of a disciplinary system is to maintain the efficiency of the service, the processes of that system must look first to this end and only secondarily toward that preservation of individual integrity which is the aim of the common-law system. ${ }^{37}$ The fact that the elements of military law concerning disciplinary offenses differ from the "due process" of civil law means only that those responsible for the operation of the army have chosen those means which their experience leads them to believe will best effect the maintenance of discipline. ${ }^{38}$ Whatever the civil courts may think of these procedures, such cases remain and should remain strictly under military control, for the training and experience of civil judges is not such as would enable them to deal effectively with the problems of military discipline.

A careful examination of the basic precedents limiting the scope of inquiry into court martial jurisdiction shows them to fall almost invariably within this "disciplinary" category, both by the nature of the offense and by the reasons given for upholding the courts martial. ${ }^{39}$ Although in many of these cases con-

${ }^{35}$ "[T] $[$ he common law . . . knew no distinction between citizen and soldier; so that if a life-guardsman deserted, he could only be sued for a breach of contract; and if he struck his officer, he was only liable to an indictment or an action of battery." 2 Campbell, Lives of the Chief Justices 91 (1873).

${ }^{36}$ Reaves v. Ainsworth, 219 U.S. 296, 304 (1911).

${ }_{37}$ "The" discipline necessary to the efficiency of the army and navy, required other and swifter modes of trial than are furnished by the common law courts." Ex parte Milligan, 4 Wall. (U.S.) 2, 123 (1866).

${ }^{38}$ The concept of due process under the Fifth and Fourteenth Amendments recognizes that different procedures may be appropriate under different conditions. See, e.g., Twining v. New Jersey, 211 U.S. 78 (1908); Wolf v. Colorado, 338 U.S. 25 (1949).

${ }^{39}$ Dynes v. Hoover, 20 How. (U.S.) 65 (1858), held that the civil courts could not void judgment of court martial with jurisdiction; however, the offense was attempted desertion, an act of purely disciplinary significance. Ex parte Reed, 100 U.S. 13, 22 (1879), denied habeas corpus relief to navy paymaster's clerk convicted of malfeasance, stating, "the good order and efficiency of the service depend largely upon the faithful performance of their duties." Accord: Johnson v. Sayre, 158 U.S. 109 (1895) (embezzlement by navy paymaster's clerk). In Smith v. Whitney, 116 U.S. 167, 169, 178 (1885), a case involving "culpable inefficiency in the performance of duty," the Supreme Court said: "Of questions not depending upon the construction of the statutes, but upon unwritten military law or usage, within the jurisdiction of courts martial, military or naval officers, from their training and experience in the service are more competent judges than the courts of common law." In re Grimley, 137 U.S. 147 (1890), which stated that civil courts could enquire only into the jurisdiction of courts martial, concerned desertion by fraudulent enlistee. Swaim v. United States, 165 U.S. 553 (1897), dismissing a suit to recover pay forfeited under a court martial judgment, dealt with the catch-all "conduct to the prejudice of good order and military discipline" (now UCMJ Art. 134). Carter v. McClaughry, 183 U.S. 365, 390 (1902), a case of fraud against the government by army officer, held habeas corpus would not question sentence of court martial with jurisdiction. The Court said that the sanctity of such decisions "would seem to be essential to the maintenance of that discipline which renders the army efficient." Reaves v. Ainsworth, 219 U.S. 296, 304 (1911), saying that "the decision . . o of a military tribunal acting within the scope of its law- 
stitutional issues were raised, they were easily disposed of either on the facts of the case or on recognized principles of law..$^{40}$ In effect, then, all the due process available was that which was granted by and within the military law.

Although "disciplinary" courts martial are generally upheld, this does not mean that the denial by courts martial of substantive constitutional rights will otherwise be permitted, for although the language used in the "disciplinary" cases is often general, it must nevertheless be read in the full context of the facts and holdings of those cases in order to constitute binding precedent.

II

The other category of offense, the "criminal," is concerned with civil crimes committed by servicemen. ${ }^{11}$ The offenses encompassed here are those which have only an ancillary effect upon the service and primarily concern the persons directly involved. Since these are the deeds of individuals in relationship to other individuals, rather than those of members of an organization in relationship to that organization, few problems are raised concerning the special effect of such deeds upon the service. While it is true that any action of a serviceman reflects to some degree upon his uniform, the effect of his civil crimes upon the internal efficiency of the service is slight ${ }^{42}$-despite public-relations headaches. ${ }^{43}$ Therefore, since these offenses are of the type normally dealt with by the criminal courts, and since no such problems of discipline are raised as would justify trial by other than the traditional common-law methods, the offenders are generally turned over to the civil authorities. ${ }^{44}$

ful powers cannot be reviewed," held inviolable the findings of board of examiners convened to determine mental and physical qualifications of junior officers. French v. Weeks, 259 U.S. 326 (1922), and Creary v. Weeks, 259 U.S. 336 (1922), also upheld military tribunals determining capacity and fitness for command.

${ }^{10}$ Smith v. Whitney, 116 U.S. 167 (1886) (right to jury trial preserved but not expanded by Sixth Amendment); Carter v. McClaughry, 183 U.S. 365 (1902) (double jeopardy disposed of on facts of case); Johnson v. Sayre, 158 U.S. 109 (1895) (grand jury indictment unnecessary at any time for "cases arising in the land or naval forces" by the plain words of the Fifth Amendment); Reaves v. Ainsworth, 219 U.S. 296 (1911), French v. Weeks, 259 U.S. 326 (1922), Creary v. Weeks, 259 U.S. 336 (1922) (military law constitutes due process regarding proper procedure for administrative board).

41 This category consists of offenses committed other than in the line of duty, such as robbery of a civilian. Insofar as a criminal act also constitutes a substantial breach of discipline, it could legitimately be considered in the "disciplinary" category. See note 44 infra.

42 Since "criminal" offenses do not strike directly at the organization, their effect on it is limited to the loss of the offender's services during his confinement, plus the desire to emulate such offence roused in other members of the service. However, a proper trial is sufficiently likely to convict the guilty and is as good a deterrent as an improper trial, which is more likely to convict the innocent.

is The fact that all members of a clearly defined minority group are blamed for the bad deeds of a few of their number does not give such a group the right to go beyond the criminal law in policing its own members.

${ }^{14}$ At first glance, it would seem that Ex parte Mason, 105 U.S. 696, 698, 699 (1881), was an exception to this rule, since it concerned a court martial trial of the attempted murder of a civilian by a soldier. However, the case had an immediate and direct disciplinary significance, 
The first Articles of War, promulgated in 1775,45 limited court martial power over crimes committed by members of the armed forces to the trial of those acts which actually affected good order and military discipline; ${ }^{46}$ in such cases the military and the local civil courts had concurrent jurisdiction. In 1776, this concurrent jurisdiction was specifically set forth in the Articles of War, ${ }^{47}$ giving the civil courts "if not a supremacy of jurisdiction, at least a primary power to proceed against military offenders violating the civil law." 48 Later, again by statute, ${ }^{49}$ courts martial were specifically given power over various nondisciplinary crimes committed in wartime. Prior to this statute such crimes apparently "had not in practice been treated as within the grant of authority to deal with them as prejudicial to good order and military discipline." ${ }^{150}$ Insofar as courts martial were used for the trial of soldier-criminals the reason was not to supplant the local criminal laws but to aid in their enforcement when, for any reason, the local courts might be unable to act upon the offender. ${ }^{51}$

The civil courts" "primary power to proceed" against soldier-criminals in peacetime was for a long time absolute; the early Articles of War unqualifiedly required military commanders to surrender civil offenders to the local authorities upon proper demand..$^{52}$ In 1916, this requirement was modified to keep within army jurisdiction those offenders against whom court martial action was already being or had been taken. ${ }^{53}$ Article of War 92 categorically forbade trial by court martial for murder or rape committed in the United States in peacetime. ${ }^{54}$

The effect of the foregoing Articles of War was to give the soldier-criminal in most cases a civil trial necessarily conforming to the accepted civil standards of due process; the reason for those articles presumably lay in "the known hostility of the American People to any interference by the military with the regular ad-

since the intended victim was a prisoner under the defendant's guard. "[S]hooting by a soldier of the army standing guard over a prison, with intent to kill a prisoner confined therein, is not only a crime against society, but an atrocious breach of military discipline." Moreover, even here the civil courts would have been given jurisdiction had they taken any steps to proceed against the offender. See also Neall v. United States, 118 Fed. 696 (C.A. 9th, 1902).

$451 \mathrm{~J}$. Cont. Cong. 90 (1775). These Articles and the material used in notes 47-54 infra and accompanying text are taken in large measure from Caldwell v. Parker, 252 U.S. 376 (1920), and Winthrop, op. cit.supra note 2, at 11-15.

${ }^{46}$ Cf. Re Stubbs, 133 Fed. 1012 (C.C. Wash., 1905) (soldier shot and wounded a comrade while on duty).

$471 \mathrm{~J}$. Cont. Cong. 435, 482 (1776).

48 Caldwell v. Parker, 252 U.S. 376, 382 (1920).

4912 Stat. 736 (1863).

${ }^{50}$ Caldwell v. Parker, 252 U.S. 376, 383 (1920).

${ }^{51}$ Ibid., at 386. The local courts might be closed because of the existence of martial law or military operations. Winthrop, op. cit. supra note 2, at 1033.

${ }^{52}$ Code of 1776, Art. $1, \S 10,1$ J. Cont. Cong. 435, 482 (1776); Arts. 33, 99, 2 Stat. 359 (1806); Art. 59, Rev. Stat. \$1342 (1878).

${ }^{53}$ Art. 74, 39 Stat. 662 (1916). Cf. McKittrick v. Brown, 337 Mo. 281, 85 S.W. 2d 385 (1935).

5441 Stat. 787 (1920). 
ministration of justice in the civil courts." ${ }^{55}$ Under the new Uniform Code of Military Justice, ${ }^{56}$ however, surrender of an offender to the civil authorities is not made mandatory by statute, but is left dependent upon administrative regulations. ${ }^{57}$ Moreover, there is a group of criminal cases where the offender must necessarily be tried by court martial, but where his right to the protection of due process should remain-criminal offenses by United States servicemen in foreign countries..$^{58}$ Our courts have always taken the view that such cases must be tried by court martial rather than by the foreign courts. ${ }^{59}$ Yet, although such crimes have a somewhat greater disciplinary significance than if committed at home, they appear to remain basically within the "criminal" category. ${ }^{60}$ The large number of American servicemen now stationed overseas, plus the fact that the Code makes the major civil crimes court martial offenses, ${ }^{61}$ means that the soldier-criminal no longer has the same rights as before to a civil trial with its concomitant of due process. Only by insisting on due process in criminal courts martial can the courts create equivalent rights. Since the services, of necessity, strive for uniformity, this may well result in an extension of due process by the armed forces to "disciplinary" courts martial as well-a not undesirable result.

\section{III}

The contrast between the traditional treatment of "criminal" offenses, which were seldom left to court martial when a civil court was available, and that of "disciplinary" cases, where sole and complete court martial jurisdiction has never been challenged, reinforces the conclusion that these two basic categories do exist within the court martial field. ${ }^{62}$ By making use of these categories, the conflict between "due process" and the precedent-based inviolability of court martial decisions can be resolved. Now that a hundred years of precedent based on the exigencies of maintaining military discipline have sealed off the "disciplinary" cases from substantial interference by the civil courts, the military must there be trusted to temper efficiency with justice. The criminal cases, how-

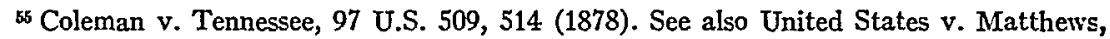
49 F. Supp. 203 (M.D. Ala., 1943).

${ }^{5 B}$ Op. cit. supra note 33 .

${ }^{57}$ UCMJ Art. 14. The present regulations state as a matter of policy that civil offenders should be surrendered unless the best interest of the service would be prejudiced thereby. Army Regs. 600-320 C 1. Cf. Wiener, op. cit. supra note 31, at 5, 62-63.

${ }^{58}$ Of course such combat offenses as looting are purely disciplinary.

${ }^{59}$ Schooner Exchange v. M'Faddon, 7 Cranch (U.S.) 116 (1812).

${ }^{60}$ See text and notes at notes 42 and 43 supra. In addition, one of the finest aspects of American life is the system of justice that gives every man a fair trial-this we should not fear to reveal to both friend and foe in other lands.

${ }^{61}$ UCMJ Arts. 118-31. See also Wiener, op. cit. supra note 31, at 21-22; Index and Legislative History of UCMJ, House Hearings $1237 \mathrm{ff}$.

${ }^{62}$ Contemporary recognition of the dichotomy is contained in both American and British legal periodicals: Holtzoff, Administration of Justice in the U.S. Army, 22 N.Y.U.L.Q.Rev. 1, 2 (1947); Griffith, Justice and the Army, 10 Modern L. Rev. 292, 300-303 (1947). 
ever, have always been subject in one way or another to a large measure of civilian influence. Since no valid reason exists for removing this influence, it would seem appropriate that it be exercised through a standard of collateral attack requiring the same due process for court martial trial of soldier-criminals as is necessary in the civil trial of all criminals.

Such an extension of due process is suggested by Grafton $v$. United States:63 Congress, by express constitutional provision, has the power to prescribe rules for the government and regulation of the Army, but these rules must be interpreted in connection with the prohibition against a man's being put twice in jeopardy for the same offense. The former provision must not be so interpreted as to nullify the latter.

Or, as was more recently stated: $:^{64}$

We think this basic guarantee of fairness afforded by the due process clause of the fifth amendment applies to a defendant in criminal proceedings in a federal military court as well as in a federal civil court. An individual does not cease to be a person within the protection of the fifth amendment of the Constitution because he has joined the nation's armed forces.

The decisive rejection of writs of certiorari and prohibition as means of collateral attack ${ }^{65}$ has left habeas corpus as the major weapon for overturning court martial judgments in the civil courts. ${ }^{66}$ The writ of habeas corpus remains subject to the limitation that it will not, in general, support consideration of the guilt or innocence of the accused or the procedure at the trial, but will lie only to determine the "jurisdiction" of the court. ${ }^{67}$ The concept of jurisdiction in civil cases, however, appears to have been expanded to include substantial compliance with the constitutional rights of the accused.

In the federal civil court system it is settled by clear statutory mandate that habeas corpus will free the victim of an unconstitutionally conducted trial..$^{68}$ The tie-in between constitutionality and jurisdiction was well expressed in Johnson v. Zerbst: ${ }^{69}$

A court's jurisdiction at the beginning of trial may be lost "in the course of the proceedings" due to failure to complete the court . . . by providing counsel for an accused. ... If this requirement of the Sixth Amendment is not complied with, the court no longer has jurisdiction to proceed. The judgment of conviction pronounced by a court without

${ }^{63} 206$ U.S. 333, 352 (1907). See also Sweeney v. Hiatt, 89 F. Supp. 416 (N.D. Ga., 1949).

64 United States ex rel. Innes v. Hiatt, 141 F. 2d 664 (C.A. 3d, 1944).

${ }^{65}$ In re Vidal, 179 U.S. 126 (1900); Smith v. Whitney, 116 U.S. 167 (1886); cf. Winthrop, op. cit. supra note 2, at 55-60.

${ }^{66}$ Suit in the Court of Claims for forfeited pay is another remedy. Shapiro v. United States, 69 F. Supp. 205 (Ct. Cl., 1947).

${ }^{67}$ Petitioner must first have exhausted his other remedies. Gusik v. Schilder, 340 U.S. 128 (1950). And habeas corpus will only free one held in physical as against moral restraint. Wales v. Whitney, 114 U.S. 564 (1885). Nor can habeas corpus grant an honorable or void a dishonorable discharge. Miller v. Commanding Officer, 57 F. Supp. 884 (N.D. Tex., 1944).

68 14 Stat. 385 (1867), as amended, 28 U.S.C.A. $\$ 2241$ (c)(3) (1950). In re Nielson, 131 U.S. 176, 182 (1889).

09304 U.S. 458, 468 (1938). 
jurisdiction is void, and one imprisoned thereunder may obtain release by habeas corpus.

Even in the sphere of federal-state court relations,

the use of the writ [of habeas corpus] in the federal courts to test the constitutional validity of a conviction for crime is not restricted to those cases where the judgment of conviction is void for want of jurisdiction of the trial court to render it. It extends also to those exceptional cases where the conviction has been in disregard of the constitutional rights of the accused, and where the writ is the only effective means of preserving his rights. ${ }^{70}$

Therefore, it seems clear that habeas corpus review of unconstitutional civil trials has become an accepted method of protection for the victims of such trials. Even where (state) corrective judicial procedure is provided for, federal habeas corpus action will serve to correct error made therein with regard to the constitutional question. ${ }^{71}$

The question of what constitutes a denial of due process in "criminal" court martial cases is one that can be answered only on the facts of each individual case. $^{72}$

As applied to a criminal trial [in State courts under the Fourteenth Amendment] denial of due process is the failure to observe that fundamental fairness essential to the very concept of justice. In order to declare a denial of it we must find that the absence of that fairness fatally infected the trial; the acts complained of must be of such quality as necessarily prevents a fair trial. ${ }^{73}$

This differs from the rule set forth in Reaves v. Ainsworth" that "to those in the military or naval service of the United States the military law is due process." This does not necessarily indicate a conflict, for the Articles of War and military precedents require, in theory at least, all elements essential to fairness. ${ }^{75} \mathrm{How}$ ever, even if there were such a conflict, constitutional considerations should take precedence over even the broad wording-as distinguished from the narrow holding - of the Reaves case. The Supreme Court has held the constitutional right to counsel dependent not on the normal (state) procedures, but on the fun-

70 Waley v. Johnston, 316 U.S. 101, 104-5 (1942).

71 Williams v. Kaiser, 323 U.S. 471 (1945).

72 Many of the elements of an unconstitutional trial have been recognized and proscribed in holding or dicta by the Supreme Court in habeas corpus attack on both state and federal convictions. Mooney v. Holohan, 294 U.S. 103, 112 (1935) (testimony known by prosecutor to be materially perjured); Walker v. Johnston, 312 U.S. 275 (1941) (absence of counsel unless intelligently waived); von Moltke v. Gilles, 332 U.S. 708 (1948) (plea of guilty obtained by trickery); in re Oliver, 333 U.S. 257 (1948) (secret trial); Watts v. Indiana, 338 U.S. 49 (1949) (coerced confession); Moore v. Dempsey, 261 U.S. 86 (1923) (mob hysteria); Pyle v. Kansas, 317 U.S. 213 (1942) (suppression of favorable evidence); Ex parte Nielson, 131 U.S. 176 (1889) (double jeopardy).

72 Lisenba v. California, 314 U.S. 219, 236 (1941). Cf. Lewis v. Sanford, 79 F. Supp. 77, 78 (N.D. Ga., 1948); Kuykendall v. Hunter, 187 F. 2d 545 (C.A. 10th, 1951).

" 219 U.S. 296, 304 (1911).

${ }^{75}$ See, e.g., UCMJ Arts. 31, 32, 34, 35, 37, 38, 40, 41, 44, 46, $97,98$. 
damental fairness notions of due process..$^{76}$ Of course the basic uncertainty as to what facts actually amount to a denial of fundamental fairness does much to confuse the issue of just when habeas corpus should lie, but once the courts accept the principle that an unconstitutional court martial will not be respected, fixing the details of what constitutes a fatal defect will not be difficult.

\section{IV}

In conclusion, it seems that much of the confusion and uncertainty concerning habeas corpus review of "criminal" courts martial can be removed without violating either precedent, justice, or logic. There are clearly two categories of court martial offense, "disciplinary" and "criminal." The unique factors requiring trial under military standards of due process affect only the former-in the latter the basic factors are those also extant in civil trials. Although the language of the basic precedent cases is often general, examination of their facts and holdings shows that they almost invariably fall within the "disciplinary" category, and are not on their reasoning applicable to "criminal" cases; thus the latter may be decided on the same logical grounds as criminal due process cases in the civil courts, unaffected by the precedents which so greatly limit collateral attack on "disciplinary" convictions. Courts martial, although separate from the civil court system, are not exempted from the Bill of Rights, and the expanded writ of habeas corpus is widely used to void unconstitutional convictions. Therefore, not only should it be uneasily stated that habeas corpus can free the victim of an unconstitutional court martial; it should be firmly stated as the rule and so held in appropriate cases.

${ }^{76}$ Wade v. Mayo, 334 U.S. 672 (1948).

\section{SHAM MARRIAGES}

In the recent federal case of United States $v$. Lutwak, ${ }^{1}$ several aliens and American citizens were prosecuted for conspiring to violate Sections 180a and 220(c) of Title 8 of the United States Code, ${ }^{2}$ each of which provisions forbids obtaining entry into the United States by willfully false or misleading representations, statements, or documents required by the immigration laws; and for defrauding the United States of its governmental functions and its immigration laws. Three American citizens had participated in marriage ceremonies with the aliens in order that the latter would be eligible for admission into the United States under the War Brides Act of 1945. ${ }^{3}$ Upon a finding that the parties had agreed not to

1195 F. 2d 748 (C.A. 7th, 1952), aff'd, Lutwak v. United States, 344 U.S. 604 (1953).

245 Stat. 1551 (1929), 8 U.S.C.A. $\$ 180$ a (1942), makes it a misdemeanor to obtain entry into the United States by a willfully false or misleading representation or the willful concealment of a material fact. 43 Stat. 165 (1924), 8 U.S.C.A. $\$ 220$ (c) (1942), provides for a maximum fine of $\$ 10,000$ or a maximum imprisonment for five years or both for knowingly making under oath any false statement, affidavit, or other document required by the immigration laws or regulations prescribed thereunder.

${ }^{3} 59$ Stat. 659 (1945), 8 U.S.C.A. $\$ \$ 232-36$ (Supp., 1952), dealing with admission of alien spouses and minor children of citizen members of the armed forces during World War II. 